\title{
Histophagous ciliate Pseudocollinia brintoni and bacterial assemblage interaction with krill Nyctiphanes simplex. II. Host responses
}

\author{
Jaime Gómez-Gutiérrez ${ }^{1, *}$, Jorge A. Del Angel-Rodríguez ${ }^{2,4}$, Nelly Tremblay ${ }^{1,5}$, \\ Tania Zenteno-Savín ${ }^{2}$, Mario J. Aguilar-Méndez ${ }^{2,6}$, Alejandro López-Cortés ${ }^{2}$, \\ Carlos J. Robinson ${ }^{3}$ \\ ${ }^{1}$ Instituto Politécnico Nacional, Centro Interdisciplinario de Ciencias Marinas (CICIMAR), \\ Departamento de Plancton y Ecología Marina, La Paz, BCS 23096, Mexico \\ ${ }^{2}$ Centro de Investigaciones Biológicas del Noroeste (CIBNOR), La Paz, BCS 23096, Mexico \\ ${ }^{3}$ Instituto de Ciencias del Mar y Limnología, Universidad Nacional Autónoma de México (UNAM), Mexico City, DF 04510, Mexico \\ ${ }^{4}$ Present address: Departments of Biology and Ocean Sciences, Memorial University of Newfoundland, St. John's, \\ NL A1C 5S7, Canada \\ ${ }^{5}$ Present address: Instituto Politécnico Nacional, Centro de Investigación y de Estudios Avanzados (CINVESTAV) - \\ Unidad Mérida, Departamento de Recursos del Mar, Mérida, Yucatán 97310, Mexico \\ ${ }^{6}$ Present address: Instituto Politécnico Nacional, Unidad Profesional Interdisciplinaria de Ingeniería Guanajuato (UPIIG), \\ Guanajuato 36275, Mexico
}

\begin{abstract}
Unlike decapod crustaceans of commercial interest, the krill defense system and its response to parasites and pathogens is virtually unknown. Histophagous ciliates of the genus Pseudocollinia interact with at least 7 krill species in the northeastern Pacific. Although they can cause epizootic events, the physiology of the histophagous ciliate-host interaction and krill (host) defenses remain unknown. From 1 oceanographic survey along the southwestern coast of the Baja California Peninsula near Bahía Magdalena and 2 in the Gulf of California, we investigated parasitoid-host physiological responses (fatty acid and oxidative stress indicators) of the subtropical krill Nyctiphanes simplex infected with the ciliate P. brintoni. All life stages of P. brintoni were associated with opportunistic bacterial assemblages that have not been explicitly investigated in other Pseudocollinia species ( $P$. beringensis, $P$. oregonensis, and $P$. similis). Parasitoid ciliates exclusively infected adult females, which showed increased lipid content during gonad development. As the infection progressed, omega-3 eicosapentaenoic and docosahexaenoic fatty acids, which may act as energy sources to produce high numbers of ciliate transmission stages, were quickly depleted. Antioxidant enzymes, components of the crustacean defense system, varied throughout infection, but without inhibiting Pseudocollinia infection, i.e. higher levels of lipid oxidative damage were detected in late stages of infection. The ineffective response of the krill antioxidant defense system against histophagous ciliates and the bacteria associated with the ciliates suggests that Pseudocollinia ciliates are functionally analogous to krill predators and may have a strong influence on the population dynamics of krill.
\end{abstract}

KEY WORDS: Apostome ciliates - Euphausiacea - Parasite-host association - Fatty acids · Oxidative stress · Eicosapentaenoic acid · Docosahexaenoic acid · Glutathione S-transferase

\section{INTRODUCTION}

The perspective is advancing that parasites and pathogens play a relevant role in marine pelagic food webs, interacting with planktonic organisms. Dinoflagellates play a major role in controlling phytoplankton blooms (Peacock et al. 2014) and killing the eggs of planktonic copepods and krill (Gómez- 
Gutiérrez et al. 2009). Other protists, such as apostome ciliates of the genus Pseudocollinia, can cause epizootic events of adult krill populations (GómezGutiérrez et al. 2003). Research on histophagous ciliates infecting krill has mostly focused on taxonomic perspectives and biology (Capriulo \& Small 1986, Capriulo et al. 1991, Stankovic \& RakusaSuszczewski 1996, Gómez-Gutiérrez et al. 2003, 2006, 2010a, 2012a, Lynn et al. 2014). Considerably less is known about aspects of Pseudocollinia ecology, parasite-host interactions, and physiological and biochemical composition between healthy and Pseudocollinia-infected krill. Gómez-Gutiérrez et al. (2015, this issue) proposed that P. brintoni GómezGutiérrez et al., 2012 infects the neritic subtropical krill Nyctiphanes simplex Hansen, 1910 by trophic transfer. Previously, other infection pathways were rejected, such as cuticle penetration (as Synophrya spp. does) (Bradbury \& Goyal 1976, Johnson \& Bradbury 1976, Bradbury 1994), and infection by krill mating (Gómez-Gutiérrez et al. 2006). The trophic infection mechanism was indirectly evidenced by comparing bacterial communities inhabiting the stomachs of healthy krill and those detected in the hemocoel of specimens infected with $P$. brintoni (Gómez-Gutiérrez et al. 2015). However, little is known about the immune system response and physiological changes of krill (Zhao et al. 2011, 2013, Seear et al. 2012), resulting in a poor and fragmented understanding about the effect of pathogens and parasites on euphausiids. Here we explored how the fatty acids and oxidative stress enzymes of N. simplex respond to histophagous ciliate infections through the different endoparasitic life phases that typically last a few days (Gómez-Gutiérrez et al. 2006, 2012a).

Pathogen and parasite infections can provoke an imbalance between the production of reactive oxygen species (ROS; chemically reactive molecules containing oxygen) and the antioxidant defenses and results in the so-called oxidative stress response. To fight infections, crustaceans react with a massive release of ROS or an oxidative burst produced by the immunocytes that support lysosomal enzymes to eliminate the undesirable components (Philipp et al. 2011). This is the basis for using oxidative stress indicators to detect the effects of a parasitic infection. The response of krill or other key zooplankton organisms to Pseudocollinia, pathobiont bacteria (bacteria with pathogenic potential), or other types of pathogenic organisms has not been investigated. The opportunistic bacteria Psychrobacter and Pseudoalteromonas infect the Antarctic krill Euphausia superba Dana, 1850 and are always associated with black spots (melanized nodules) on the cuticle (Miwa et al. 2008). Black spots have not yet been observed in any krill species in the northeastern Pacific (J. Gómez-Gutiérrez pers. obs.). The krill antimicrobial responses may be assumed to be similar to those of other crustaceans, based on similarities among crustacean defense systems and biological responses of commercial species, such as shrimp (ParrillaTaylor et al. 2013), crabs (Xu et al. 2013), or freshwater crayfish (Liu et al. 2013) exposed to viral or bacterial infections. Only recent research on E. superba expression of immune genes (cathepsins $\mathrm{C}$ and $\mathrm{K}$ and C-type lectins) (Seear et al. 2012) and isolation of antimicrobial peptides (Zhao et al. 2011, 2013) provide the first clues about krill defenses against pathogens and parasites.

We integrated information obtained from 1 oceanographic survey along the coast of the Baja California Peninsula near Bahía Magdalena in December 2004 and 2 cruises in the Gulf of California in November 2005 and January 2007 to investigate physiological responses of krill $N$. simplex to infection by the apostome ciliate $P$. brintoni, with 2 objectives: (1) to establish the changes in fatty acid content during known histophagous ciliate developmental phases to infer energy transfer; and (2) to examine the defense response of the host krill to Pseudocollinia infection by studying oxidative stress indicators (antioxidant enzymes and lipid oxidative damage). This multidisciplinary study of $P$. brintoni was undertaken to understand the host-histophagous ciliate interaction from a biochemical perspective.

\section{MATERIALS AND METHODS}

\section{Krill samples}

Nyctiphanes simplex that were infected with the apostome ciliate Pseudocollinia brintoni were analyzed for oxidative stress parameters. The krill were collected along the southwestern coast of the Baja California Peninsula near Bahía Magdalena in December 2004 (Gómez-Gutiérrez \& Robinson 2006). Total lipid and total polyunsaturated fatty acid content were analyzed in krill from Bahía Magdalena collected in December 2004 and from the Gulf of California in November 2005 and January 2007. Hydroacoustic detection and field sampling methods for krill are described in detail elsewhere (GómezGutiérrez \& Robinson 2006, Gómez-Gutiérrez et al. 2010a,b, 2012a,b, Tremblay et al. 2010). 


\section{Total lipid and total polyunsaturated fatty acid content of Pseudocollinia and N. simplex}

Total lipid content and fatty acids were analysed from healthy $N$. simplex larvae (calyptopis and furcilia), juveniles, adult males, immature females (Stage I in oogonia), mature females (Stage III in vitellogenesis), and gravid females (Stage IV in meiosis), as well as from infected adult females. Healthy females (HF; $\mathrm{n}=5$ ) were used as controls for fatty acid analyses. Although fatty acid composition was determined in infected krill at 5 phases (Table 1), we combined them to increase sample size $(n=7)$ and estimate mean and $95 \%$ confidence intervals of the mean of the 12 most abundant fatty acid lipids. Pseudocollinia life phases are illustrated by Gómez-Gutiérrez et al. (2006, 2012a). During the cruises, control (healthy females) and infected krill specimens were placed in sealed containers (cryovials), frozen, transported in liquid nitrogen, and stored at $-80^{\circ} \mathrm{C}$ until needed for biochemical analyses. In the laboratory, specimens were freeze-dried for $24 \mathrm{~h}$ and dry weight was measured with a microbalance (Cahn C-33, Thermo Fisher Scientific). Single freeze-dried krill were homogenized, re-hydrated, and lipids extracted (Folch et al. 1957). Lipids were determined (Marsh \& Weinstein 1966), and the lipid extract was derivatized with hydrochloric acid and methanol 5:95 and heated at $85^{\circ} \mathrm{C}$ for $2.5 \mathrm{~h}$ (Sato \& Murata 1988) to obtain fatty acid methyl esters (FAMEs), which were recovered in pure hexane and analyzed in an HP-GCD1800B gas chromatograph with a mass spectrometer detector on a $30 \mathrm{~m} \times 0.25 \mathrm{~mm} \times 0.25 \mu \mathrm{m}$ Omega wax 250 column (Supelco). FAME peaks were identified by retention time of standards and mass spectra interpretation, and quantified by interpolation of peak areas with a calibration curve of 37 fatty acid standards (Supelco 47885-U) (Carreón-Palau et al. 2013). The relative contribution of each fatty acid to the overall fatty acid composition was computed, and differences among groups were calculated.

\section{Oxidative stress indicators as components of the crustacean immune defense system}

\section{Viable bacteria count}

To link the potential oxidative stress response (ROS burst) to bacterial infection, the bacterial assemblage was retrieved from stomach and hemocoel of live specimens. Tissues were aseptically dissected with forceps on board the research vessel immediately after krill were collected. Stomachs of healthy females were homogenized or $500 \mu \mathrm{l}$ of infected hemocoel lymph (extracted using sterile pipette tips) were immersed in $1 \mathrm{ml}$ of half-concentration of standard synthetic seawater. An aliquot of $100 \mu \mathrm{l}$ of fresh tissue (healthy stomach, infected hemocoel, free-swimming ciliates, bacteria-ciliate aggregates) was used for serial dilutions (up to $1 \times 10^{-5}$ ) and streaked on plates with marine agar 2216 (Difco) to retrieve bacteria. Total counts of viable bacterial were made by counting colony-forming units (CFU) in each dilution. The bacterial assemblage was also sampled and incubated from stomachs of healthy females of Nematoscelis difficilis, another krill species from the same region, for comparison. Plates were incubated at $20 \pm 2.6^{\circ} \mathrm{C}$ for $48 \mathrm{~h}$ and the colonies were then counted.
Table 1. Pseudocollinia brintoni infection stages of krill Nyctiphanes simplex sampled for fatty acid analysis

\begin{tabular}{|c|c|c|c|c|}
\hline Infection stage & $\begin{array}{l}\text { Ab- } \\
\text { brev. }\end{array}$ & Krill appearance & Ciliate stage(s) & $\begin{array}{l}\text { Samples } \\
\text { (n) }\end{array}$ \\
\hline Early infection & EI & Beige color & Trophonts & 2 \\
\hline Late infection & LI & $\begin{array}{l}\text { Orange color, } \\
\text { swollen carapace }\end{array}$ & Tomonts & 1 \\
\hline Just-burst krill & BK & Ruptured carapace & $\begin{array}{l}\text { Tomonts and } \\
\text { tomites }\end{array}$ & 2 \\
\hline $\begin{array}{l}\text { Free-swimming } \\
\text { ciliates }\end{array}$ & FSC & $\begin{array}{l}\text { Ciliates outside } \\
\text { carcass }\end{array}$ & Mostly tomites & 1 \\
\hline $\begin{array}{l}\text { Bacterial + } \\
\text { ciliate } \\
\text { filaments }\end{array}$ & $\mathrm{BCF}$ & - & $\begin{array}{l}\text { Encysted phoronts; } \\
\text { bacterial aggre- } \\
\text { gations formed 1-2 h } \\
\text { after krill death }^{\mathrm{a}}\end{array}$ & h \\
\hline
\end{tabular}

Antioxidant enzymes

Before assays of enzyme activity, each specimen was homogenized in 2 volumes of phosphate buffer $(50 \mathrm{mM}$, pH 7.5; EDTA, 1 mM; phenylmethylsulfonyl fluoride, $1 \mathrm{mM}$ ) and centrifuged at $1500 \times \mathrm{g}$ for $20 \mathrm{~min}$ at $4^{\circ} \mathrm{C}$. The supernatant was used for analysis; volume varied according to the size of each krill specimen. For this reason, it was not always possible to measure all oxidative stress indicators for each specimen. Only specimens frozen in liquid nitrogen were used for the oxidative stress indicator analyses. All ox- 
idative stress indicators were measured with a spectrophotometer (Jenway Scientific). Superoxide dismutase (SOD) catalyzes the reaction of the superoxide radical into hydrogen peroxide. Total SOD activity $\left(\mathrm{n}_{\mathrm{HF}}=17, \mathrm{n}_{\mathrm{EI}}=2, \mathrm{n}_{\mathrm{LI}}=3, \mathrm{n}_{\mathrm{FSC}}=3, \mathrm{n}_{\mathrm{BCF}}=2\right)$ was measured with xanthine/xanthine oxidase as a superoxide radical-generating system and nitroblue tetrazolium as a detector (Suzuki 2000). Catalase (CAT) activity $\left(\mathrm{n}_{\mathrm{HF}}=26, \mathrm{n}_{\mathrm{EI}}=1, \mathrm{n}_{\mathrm{LI}}=3, \mathrm{n}_{\mathrm{FSC}}=3, \mathrm{n}_{\mathrm{BCF}}=3\right)$ was analyzed by measuring the decrease in hydrogen peroxide concentration at $240 \mathrm{~nm}$ (Aebi 1984). Selenium-dependent glutathione peroxidase (Se-GPx) activity $\left(\mathrm{n}_{\mathrm{HF}}\right.$ $=27, \mathrm{n}_{\mathrm{EI}}=1, \mathrm{n}_{\mathrm{LI}}=3, \mathrm{n}_{\mathrm{FSC}}=3, \mathrm{n}_{\mathrm{BCF}}=3$ ) was measured by monitoring the continuous decrease in nicotinamide adenine dinucleotide phosphate (NADPH) concentration using peroxide as a substrate (Ahmad \& Pardini 1988). Both CAT and Se-GPx neutralize hydrogen peroxide. Glutathione reductase (GR) activity $\left(\mathrm{n}_{\mathrm{HF}}=10\right.$, $\mathrm{n}_{\mathrm{EI}}=2, \mathrm{n}_{\mathrm{LI}}=1, \mathrm{n}_{\mathrm{FSC}}=2, \mathrm{n}_{\mathrm{BCF}}=1$ ) was determined by using the decrease in absorbance during oxidation of NADPH (Goldberg \& Spooner 1983). The role of this enzyme is to resupply the reduced form of glutathione in cells, a substrate used by Se-GPx and glutathione Stransferase (GST). GST activity $\left(\mathrm{n}_{\mathrm{HF}}=26, \mathrm{n}_{\mathrm{EI}}=3, \mathrm{n}_{\mathrm{LI}}=\right.$ $3, \mathrm{n}_{\mathrm{FSC}}=2, \mathrm{n}_{\mathrm{BCF}}=3$ ) was determined by monitoring the formation of the thio-ether product from the reaction between reduced glutathione (GSH) and 1-chloro, 2,4dinitrobenzene (Habig \& Jakoby 1981). This enzyme acts as a detoxifier. Soluble protein content in homogenates was measured with a kit with bovine serum albumin (500-0006, Bio-Rad Laboratories) as the standard (Bradford 1976) to get enzyme activities expressed in activity units (U) $\mathrm{mg}^{-1}$ protein.

\section{Lipid peroxidation}

Thiobarbituric acid reactive substances (TBARS) are by-products of lipid peroxidation, and their levels constitute a quantitative index of the lipid oxidative damage induced by ROS (Ohkawa et al. 1979, Persky et al. 2000). TBARS were measured in healthy females and at each infection stage of females infected with Pseudocollinia $\left(\mathrm{n}_{\mathrm{HF}}=14, \mathrm{n}_{\mathrm{EI}}=3, \mathrm{n}_{\mathrm{LI}}=3, \mathrm{n}_{\mathrm{FSC}}=3, \mathrm{n}_{\mathrm{BCF}}=3\right)$.

\section{Data analysis}

As some infection stages only had 1 sample per oxidative stress indicator, the non-parametric Kruskal-Wallis test and the non-parametric multiple comparison test from the package 'dunn.test' (Dinno 2015) in R software (R Core Team 2012) was used.

\section{RESULTS}

\section{Lipid physiology of the parasitoid-krill interaction}

All infected krill collected were mature females (9-19.2 mm total length; Fig. 1a,b). Apparently only ciliates in filaments or possibly free-swimming ciliates (tomite stage) consumed by larger females (with lipid-rich gonads) can infect and produce large numbers of free-swimming Pseudocollinia brintoni tomites by palyntomy of the tomont stages (Fig. 1b,c). Although male krill were 1.3 times heavier than females, mature females had, on average, $16 \%$ higher total lipid content and >3-fold 18:4 (n-3) fatty acid than males (Fig. 1c). Lipid content of immature females was not significantly different from males. Mature females increased their lipid content up to $70 \%$ during gonad development. Adults of both sexes had significantly more polyunsaturated fatty acids (PUFAs) than juveniles (Fig. 1c).

Comparing the mean concentration of the main 12 fatty acids standardized per dry weight $\left(>1 \mu \mathrm{g} \mathrm{m}^{-1}\right.$ DW) and $95 \%$ confidence intervals between healthy mature females $(\mathrm{n}=5)$ and females infected with $P$. brintoni $(\mathrm{n}=5)$, it was evident that infected females had a significant decrease in the fatty acid concentration after infection started, suggesting deterioration of krill homeostasis (Fig. 2). An analysis of variance (ANOVA) showed significant differences $(p<0.05)$ for all mean fatty acid concentrations and ratios (except for the ratio of highly unsaturated:saturated fatty acids [HUFA:SFA], p = 0.34) tested between healthy and infected females; the mean decrease in concentration for each main fatty acid was $64 \%$ (range $=51-90 \%$; Table 2). Specifically, the fatty acid concentrations of free-swimming ciliates and ciliates forming filaments (outside the host) were smaller than those of healthy females and infected females $(n=5)$.

\section{Oxidative stress indicators}

Bacteria count, antioxidant enzyme activities, lipid peroxidation levels (TBARS), and total lipid and fatty acid content of healthy (control) and infected $\mathrm{Nyc}$ tiphanes simplex during the $P$. brintoni life cycle are presented in Fig. 3. Average viable bacteria counts in the stomachs of healthy krill $(N$. simplex and Nematoscelis difficilis) in the Gulf of California were on the order of $8 \times 10^{5} \mathrm{CFU} \mathrm{ml}^{-1}$ (Fig. 3a). During the early infection phase in $N$. simplex, viable bacteria counts declined in the stomach and hemocoel (Fig. 3a). Antioxidant enzyme activities were vari- 


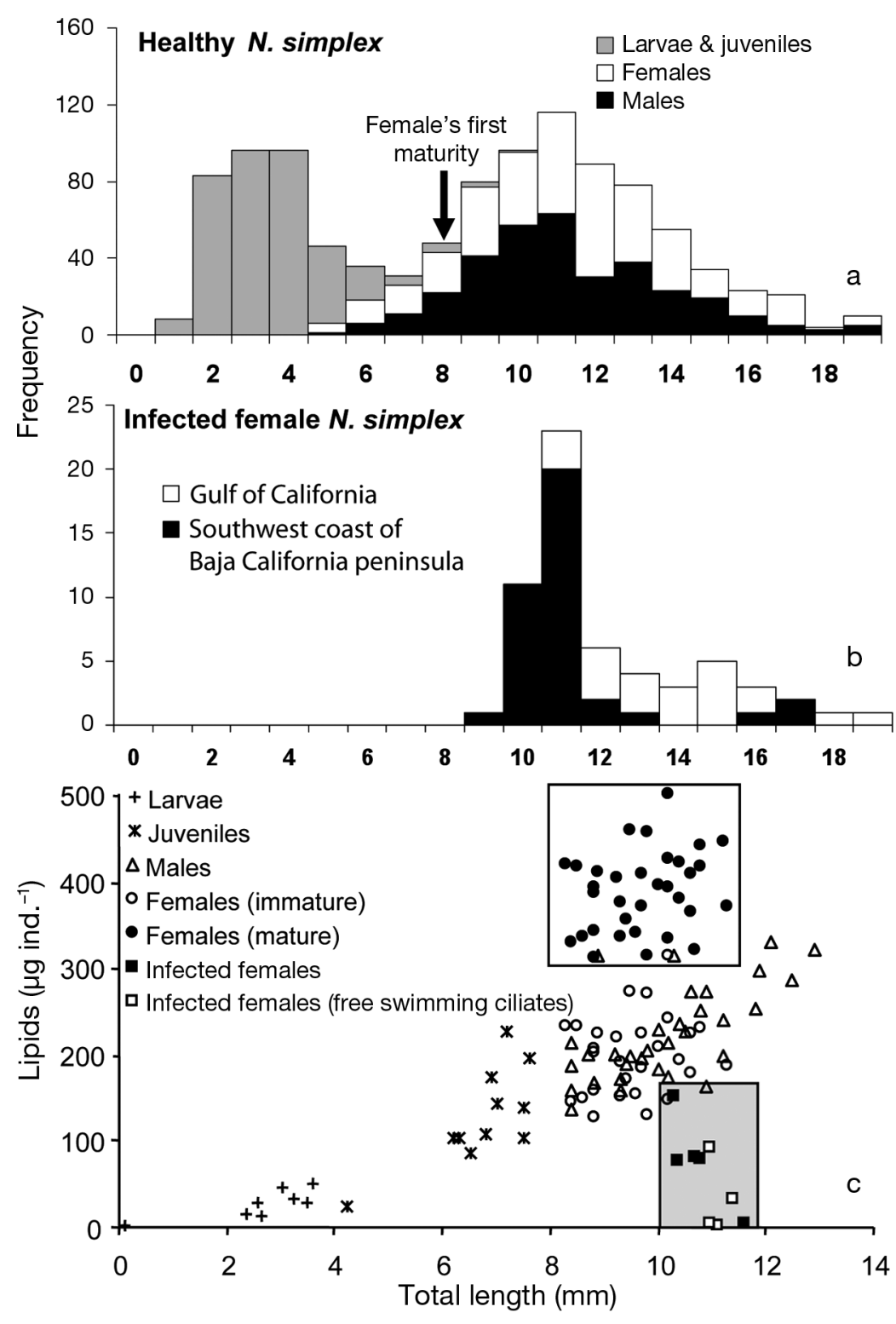

Fig. 1. Size-frequency distributions of (a) healthy Nyctiphanes simplex krill and (b) krill infected with Pseudocollinia brintoni. Samples were collected near the southwestern coast of the Baja California Peninsula (2004) and Gulf of California (Nov 2005 and Jan 2007). (c) Lipid content per krill during growth and maturation. Mature healthy females are clustered in the large open box; infected females are clustered in the gray box

bacteria-ciliate filament stages compared to healthy female and the freeswimming ciliate phase $\left(\lambda^{2}=9.41, \mathrm{p}=\right.$ 0.05; Fig. 3b). No significant difference was observed for Se-GPx activity among all Pseudocollinia infection stages (Fig. 3c). GST activity was significantly high during the late infection stage, compared to healthy females, the early infection stage, and the free-swimming ciliate phases $\left(\lambda^{2}=\right.$ 17.41, $\mathrm{p}=0.002$; Fig. 3d). Significant increases in TBARS levels were found in the early infection and bacteriaciliate filament stages $\left(\lambda^{2}=9.35, \mathrm{p}=\right.$ 0.05; Fig. 3d). Lipid peroxidation (TBARS) showed a negative association with total lipids and total fatty acid content throughout the Pseudocollinia infection process (Fig. 3e)

\section{DISCUSSION}

\section{Lipid metabolism during the Pseudocollinia infection process}

P. brintoni infection causes a sharp decrease in total fatty acid concentrations and the proportion of fatty acids during the infection, mostly decreasing the docosahexaenoic:eicosapentaenoic (DHA:EPA) ratio. Rapid depletion of long-chain fatty acids is not likely to be associated with gonad development because the endoparasitoid ciliate life span is shorter $(<3.5 \mathrm{~d})$ than the $\mathrm{Nyc}$ tiphanes simplex ovarian cycle (7-15 d; Gómez-Gutiérrez et al. 2010b, 2012b), and infected females cannot spawn, being made sterile before their death. It may not be adaptive to infect lowbiomass larvae, juveniles, or immature adults because it does not provide

able during parasitoid infection (Figs. 3b-d). SOD activity was significantly higher in healthy females, compared to the levels detected in the free-swimming ciliate and bacteria-ciliate filaments $\left(\lambda^{2}=\right.$ 11.53, p = 0.021; Fig. 3b). Similarly, GR activity was significantly higher in healthy females compared with the early and late Pseudocollinia infection phases $\left(\lambda^{2}=10.75, p=0.030\right.$; Fig. 3c). CAT activity was significantly higher during the late infection and enough energy to complete the Pseudocollinia life cycle. The changes in fatty acids during the parasitoid's life cycle suggest that it metabolizes the lipids provided by $N$. simplex. The considerable decrease in lipids during ciliate infection ( $50 \%$ or more) is not only composed of arachidonic acid (ARA), EPA, and DHA, but many other saturated and monounsaturated fatty acids and PUFAs. We did not measure prostaglandin levels; therefore, we cannot confirm 


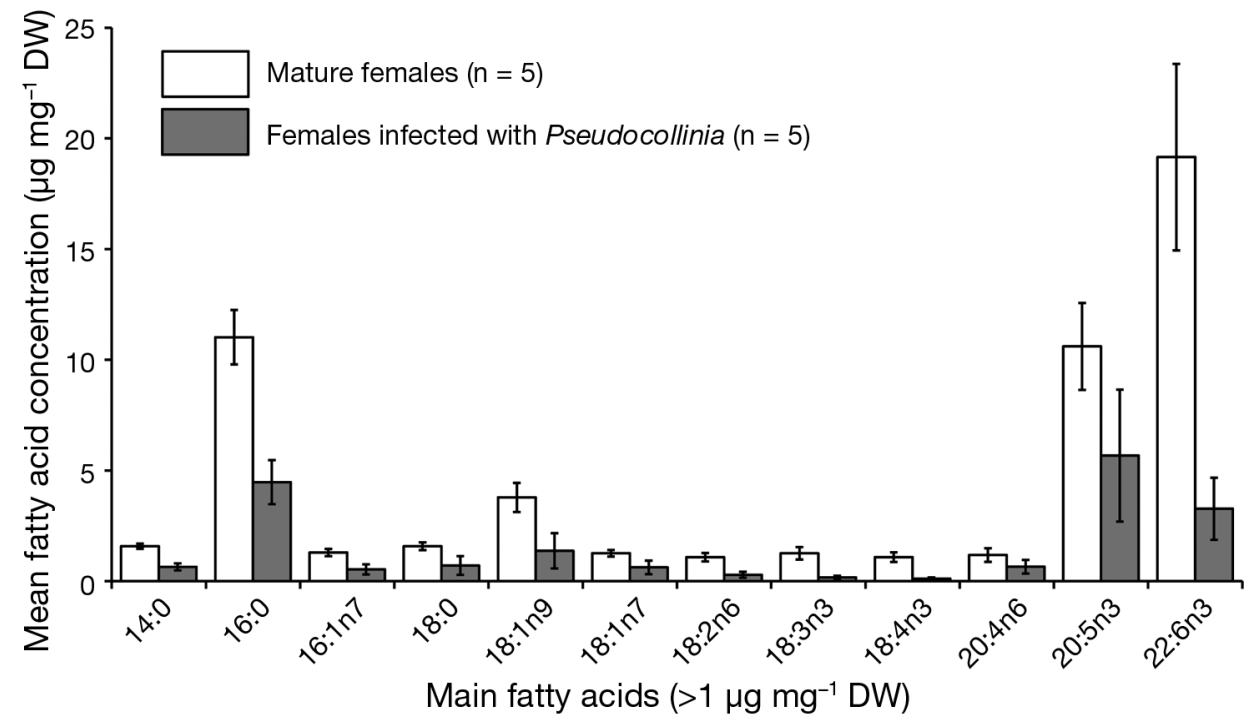

Fig. 2. Mean concentrations (and 95\% confidence intervals) of the main fatty acids (standardized per dry weight, $>1 \mu \mathrm{g} \mathrm{mg}{ }^{-1} \mathrm{DW}$ ) in mature female Nyctiphanes simplex (controls, white bars, $\mathrm{n}=5$ individuals) and females infected with Pseudocollinia brintoni (combining all available females in early and late infection stages, gray bars, $\mathrm{n}=5$ )

Table 2. Mean concentrations of the main fatty acids $\left(>1 \mu \mathrm{g} \mathrm{mg}{ }^{-1} \mathrm{DW}\right)$, fatty acid ratios, and confidence intervals $( \pm 95 \% \mathrm{CI})$ of healthy mature Nyctiphanes simplex females, females infected with Pseudocollinia brintoni ciliates $(\mathrm{n}=5)$, and free-living ciliates and filaments $(\mathrm{n}=5)$. Bold values represent the highest $(>70 \%)$ decrement from healthy to infected females. Bold $\mathrm{p}$ values represent significant differences in fatty acid concentration between healthy and infected females. SFA: saturated fatty acids; MFA: monounsaturated fatty acids; PUFA: polyunsaturated fatty acid; HUFA: highly unsaturated fatty acids; TFA: total fatty acids

\begin{tabular}{|c|c|c|c|c|c|c|c|c|c|}
\hline \multirow{3}{*}{$\begin{array}{l}\text { Main } \\
\text { fatty acids }\end{array}$} & \multirow{2}{*}{\multicolumn{2}{|c|}{$\begin{array}{c}\text { Healthy } \\
\text { mature females }\end{array}$}} & \multirow{2}{*}{\multicolumn{2}{|c|}{$\begin{array}{l}\text { Pseudocollinia- } \\
\text { infected females }\end{array}$}} & \multirow{2}{*}{\multicolumn{2}{|c|}{$\begin{array}{l}\text { Free-living Pseudocollinia } \\
\text { ciliates and filaments }\end{array}$}} & \multirow{3}{*}{$\begin{array}{c}\% \\
\text { Decrement } \\
\text { Content } \\
\left(\mu g \mathrm{mg}^{-1} \mathrm{DW}\right)\end{array}$} & \multicolumn{2}{|c|}{ ANOVA } \\
\hline & & & & & & & & $F_{1,8}$ & $\mathrm{p}$ \\
\hline & 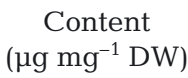 & CI & 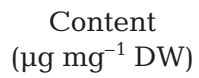 & CI & $\begin{array}{c}\text { Content } \\
\left(\mu g \mathrm{mg}^{-1} \mathrm{DW}\right)\end{array}$ & CI & & & \\
\hline $14: 0$ & 1.58 & 0.12 & 0.64 & 0.16 & 0.30 & 0.32 & 59 & 87.3 & $<0.001$ \\
\hline $16: 0$ & 11.02 & 1.23 & 4.47 & 1.00 & 2.42 & 2.74 & 59 & 65.5 & $<0.001$ \\
\hline $16: 1 \mathrm{n} 7$ & 1.29 & 0.17 & 0.53 & 0.23 & 0.46 & 0.50 & 59 & 27.6 & 0.00 \\
\hline $18: 0$ & 1.58 & 0.17 & 0.70 & 0.42 & 1.47 & 1.77 & 55 & 14.0 & 0.01 \\
\hline $18: 1 \mathrm{n} 9$ & 3.78 & 0.66 & 1.37 & 0.80 & 1.35 & 2.01 & 64 & 21.0 & 0.00 \\
\hline $18: 1 \mathrm{n} 7$ & 1.26 & 0.15 & 0.62 & 0.31 & 0.58 & 0.62 & 51 & 13.5 & 0.01 \\
\hline $18: 2 \mathrm{n} 6$ & 1.08 & 0.19 & 0.28 & 0.13 & 0.15 & 0.19 & 74 & 44.5 & $<0.001$ \\
\hline $18: 3 n 3$ & 1.26 & 0.28 & 0.17 & 0.07 & 0.05 & 0.05 & 87 & 52.9 & $<0.001$ \\
\hline $18: 4 \mathrm{n} 3$ & 1.08 & 0.22 & 0.11 & 0.06 & 0.08 & 0.09 & 90 & 68.9 & $<0.001$ \\
\hline $20: 4 n 6$ & 1.18 & 0.31 & 0.65 & 0.31 & 0.06 & 0.07 & 44 & 5.5 & 0.05 \\
\hline $20: 5 n 3$ & 10.60 & 1.96 & 5.67 & 2.98 & 0.32 & 0.35 & 47 & 7.3 & 0.03 \\
\hline $22: 6 n 3$ & 19.16 & 4.21 & 3.27 & 1.40 & 0.13 & 0.06 & 83 & 49.2 & $<0.001$ \\
\hline$\Sigma$ SFA & 16.49 & 1.51 & 6.87 & 1.80 & 5.01 & 5.44 & 58 & 64.4 & $<0.001$ \\
\hline$\Sigma \mathrm{MFA}$ & 7.25 & 1.07 & 3.19 & 1.51 & 2.82 & 3.14 & 56 & 18.5 & 0.00 \\
\hline$\Sigma$ PUFA & 35.29 & 6.87 & 10.64 & 4.91 & 1.18 & 1.00 & 70 & 32.8 & $<0.001$ \\
\hline$\Sigma \mathrm{n} 3$ & 32.47 & 6.55 & 9.40 & 4.46 & 0.65 & 0.44 & 71 & 32.6 & $<0.001$ \\
\hline$\Sigma \mathrm{n} 6$ & 2.59 & 0.40 & 0.97 & 0.44 & 0.27 & 0.27 & 62 & 28.7 & 0.00 \\
\hline$\Sigma \mathrm{C}_{18}$ PUFA & 3.45 & 0.68 & 0.58 & 0.27 & 0.32 & 0.25 & 83 & 58.9 & $<0.001$ \\
\hline HUFA:SFA & 2.05 & 0.33 & 1.63 & 0.75 & 0.23 & 0.08 & 20 & 1.0 & 0.34 \\
\hline TFA $\left(\mu g \mathrm{mg}^{-1}\right)$ & 59.03 & 8.87 & 20.69 & 5.82 & 9.01 & 9.52 & 64.9 & 50.2 & 0.00 \\
\hline$\%$ DW & 5.90 & 0.89 & 2.07 & 0.58 & 0.90 & 0.95 & 64.9 & 50.2 & 0.00 \\
\hline Total lipids ( $\left.\mu \mathrm{g} \mathrm{mg}^{-1}\right)$ & 73.92 & 11.01 & 26.78 & 13.90 & 93.19 & 103.43 & 63.8 & 27.2 & 0.00 \\
\hline
\end{tabular}

that the immune response of female krill induced some decrease in fatty acids to cope with the parasitoid infection, notably ARA, the precursor of prostaglandin E series II $\left(\mathrm{PGE}_{2}\right)$, an eicosanoid in- volved in inflammatory processes (Fig. 2, Table 1). Overall, quantitative and qualitative proportions of fatty acids changed with parasitoid infection, probably associated with (1) use of long-chain fatty acids by the 


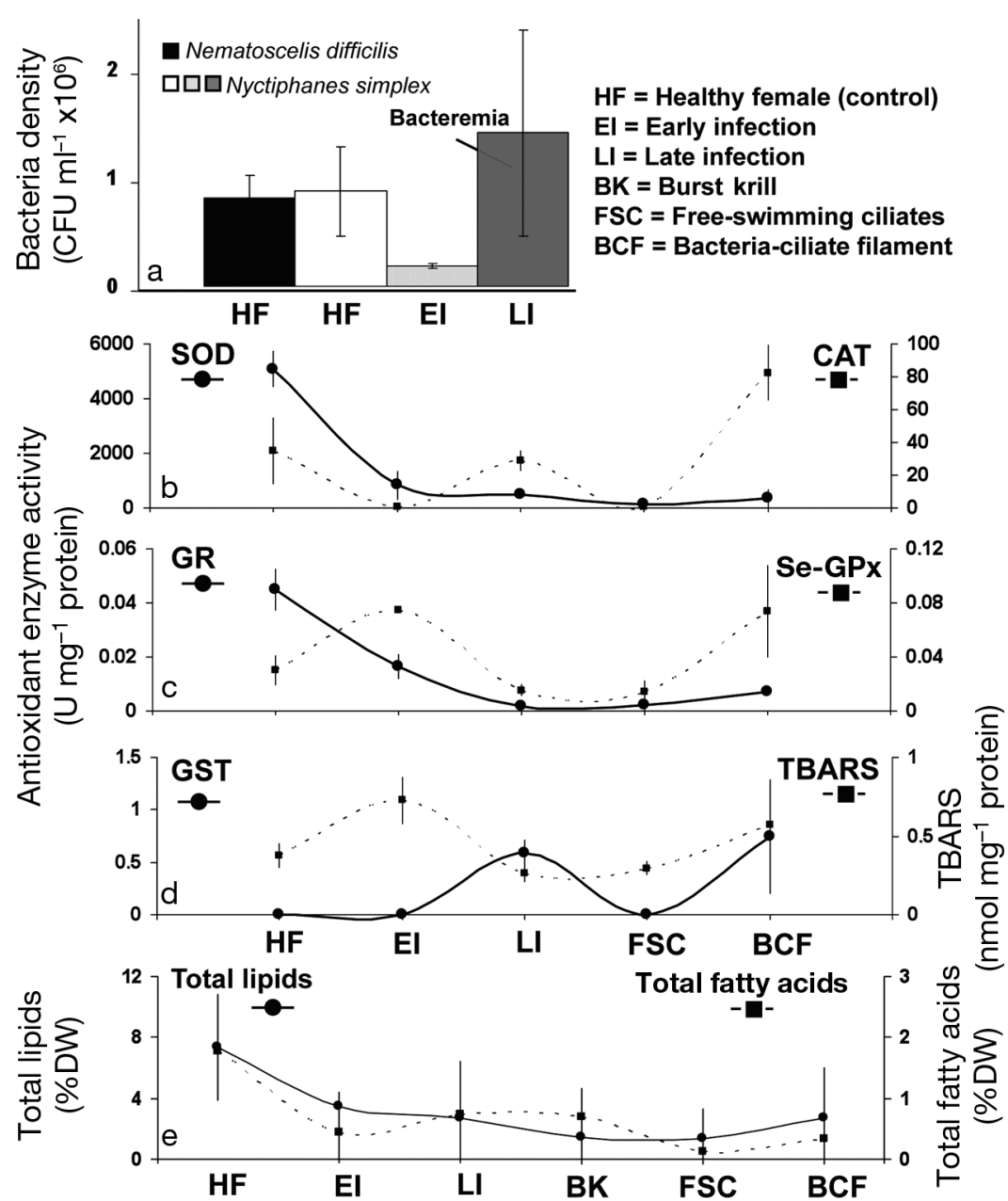

Fig. 3. Bacteria count, antioxidant enzyme activities, lipid peroxidation levels (TBARS), and total lipid and fatty acid content of healthy (control) and infected Nyctiphanes simplex during the Pseudocollinia brintoni life cycle. (a) Bacteria count (mean $\pm \mathrm{SD}$; $\mathrm{CFU} \mathrm{ml}{ }^{-1}$ ). (b-d) Antioxidant enzyme activities (mean $\pm \mathrm{SE}$; $\mathrm{U} \mathrm{mg}^{-1}$ protein): (b) superoxide dismutase (SOD) and catalase (CAT); (c) glutathione reductase (GR) and selenium-dependent glutathione peroxidase (SeGPx); (d) glutathione S-transferase (GST) and lipid peroxidation levels (TBARS; mean $\pm \mathrm{SE}_{;} \mathrm{nmol} \mathrm{mg}{ }^{-1}$ proteins). (e) Total lipid and fatty acid content per krill dry weight (mean $\pm \mathrm{SE}$; \% DW). Significant differences are described in the 'Results' raised on diets supplemented with marine algae meals rich in DHA and ARA, which show significant improvement in immune parameters, such as total hemocyte count, phenoloxidase activity, SOD activity, and bactericidal activity (Nonwachai et al. 2010). We propose the hypothesis that females are most frequently infected because juveniles and males contain relatively low levels of lipids; hence, infection does not successfully develop. In infected females, total fatty acid and total lipid content abruptly decreased; this was associated with high lipid peroxidation, as reflected in the high levels of TBARS in the early infection stage. Pseudocollinia apparently can proliferate with high rates to fulminate the host only when infecting females that have attained at least the age-length of first maturity (when they contain a high lipid content). Most infected krill collected from the Bering Sea (Thysanoessa spp.; 14-30 mm; Lynn et al. 2014), the US west coast (Euphausia pacifica and T. spinifera; 15-28 mm; Gómez-Gutiérrez et al. 2006), and the southwestern coast of Baja California Peninsula and the Gulf of California, Mexico (N. simplex; 9-19.2 mm; Gómez-Gutiérrez et al. 2012a) have been adult females (from first maturity to full maturity). Pseudocollinia does not infect exclusively female krill; Pseudocollinia-infected males have also been reported, albeit at very low prevalences (Capriulo et al. 1991, Gómez-Gutiérrez et al. 2003). ciliates, perhaps for Pseudocollinia reproductive processes; (2) host immune response through biosynthesis of eicosanoids from PUFAs (i.e. prostaglandin $\mathrm{H}_{2}$, $\mathrm{PGH}_{2}$; Stanley \& Miller 2006); and/or (3) production of the parasite's eicosanoids from host PUFAs (i.e. $\mathrm{PGE}_{2}$ ). Eicosanoids are synthesized more actively in histophagous oligohymenophorean protozoans than in free-living ciliates (Szablewski \& Hadás 1991) and serve, along with other substances, to evade or disable immune defense mechanisms of invertebrate hosts (Stanley 2000). Such nonspecific immune responses have repeatedly been reported in shrimp

\section{Antioxidants as part of the crustacean defense system against Pseudocollinia}

Muñoz et al. (2000) reported that the crustacean defense response is based on cellular and humoral components that interact to recognize and eliminate potentially infecting microorganisms. Although phagocytosis is well known in invertebrates as a mechanism to eliminate microorganisms or foreign particles, and hemocytes occur in the Antarctic krill E. superba (Alberti \& Kils 1983, Miwa et al. 2008), to date, phagocytosis or defense system mechanisms 
have not been studied in any species of Euphausiacea. Seear et al. (2012) reported that E. superba have 2 types of major immune gene: (1) cathepsins $C$ and $K$, which are in the lysosomes and endosomes that degrade intracellular or endocyte proteins, and (2) C-type lectins that contribute to innate immune responses in invertebrates, including prophenoloxidase activation, enhancement of encapsulation, nodule formation of hemocytes, formation of opsonin, antibacterial activity, antifungal activity, and healing injuries.

Antioxidant enzymes are components of the immune system of crustaceans that counteract ROS produced to deter pathogens (Belló et al. 2000, Vattanaviboon et al. 2003, Mohankumar \& Ramasamy 2006). Because we observed that concentrations of bacteria in the stomach and hemocoel decreased during the early stages of infection, we propose that a ROS burst occurred to counteract the initial inflow of bacteria entering with the ciliates through the trophic transmission pathway (Gómez-Gutiérrez et al. 2015). The ROS burst may be effective to eliminate most of the bacteria because we observed changes in bacterial assemblages over time, but insufficient to stop histophagous ciliate $P$. brintoni infection and several pathobiont bacterial strains observed in all studied $P$. brintoni infection phases (Photobacterium spp. and Pseudoalteromonas spp.; Gómez-Gutiérrez et al. 2015). Inhibition of SOD and GR activities from the first stage of infection suggests that hydrogen peroxide was present in considerable amounts and that ROS was neutralized by CAT and Se-GPx. The succession of Se-GPx action at the early stage by CAT in the late infection stage suggests that hydrogen peroxide was produced during the oxidative burst. Se-GPx and GST enzymes were never completely inhibited in any of the infection stages, even if the low activity of the GR greatly restricted the amount of reduced glutathione for the functioning of these antioxidant enzymes. As a last resort, during the late stage of infection, CAT and GST synchronized their action to cope with the ROS produced, but without success. As infected krill change color from beige to orange during Pseudocollinia infection, other non-enzymatic antioxidants could be mobilized, such as astaxanthin, which is frequently implemented in the diet of many farmed fishes for immune protection (Kiron 2012). Once Pseudocollinia annihilate the krill (bursting of the body), antioxidant enzyme activities were not detected until the formation of encysted ciliate phorontbacteria filaments (incubated several hours after death of the infected krill), showing high variability in the oxidative stress indicators.
Lipid peroxidation is not only a measure of oxidative stress, but of other sources of stress, and thus serves as an indicator of krill health (Tremblay et al. 2010). In an investigation of the vertical distribution of 3 krill species in the Gulf of California, TBARS levels of $N$. simplex were 100 times higher (mean: $16 \mathrm{nmol}$ TBARS $\mathrm{mg}^{-1}$ protein) and all enzyme activities were about 30 times higher in specimens collected in summer, compared to winter (mean: 0.22 nmol TBARS $\mathrm{mg}^{-1}$ protein) (Tremblay et al. 2010). The TBARS level in N. simplex in summer surpassed the levels of the other 2 numerically dominant krill species (Nematoscelis difficilis and E. eximia). Seasonal basal levels of lipid peroxidation and antioxidant enzyme activities, compared with krill infected with Pseudocollinia are in the range of variability of activity detected in winter (relatively low). However, lipid peroxidation, indicated by TBARS, in the early stage of infection was twice the level of healthy krill and similar to the specimens collected during winter (Tremblay et al. 2010). With this field evidence, we conclude that it is unlikely that the krill antioxidant defense system can overcome a Pseudocollinia infection once it starts.

Muñoz et al. (2000) reported that bacteria, including Vibrio strains, induced superoxide anion $\left(\mathrm{O}_{2}{ }^{-}\right)$ production in hemocytes of the whiteleg shrimp Litopenaeus vannamei, in a dose-dependent manner. Because a pathogenic strain of Vibrio harveyi failed to produce $\mathrm{O}_{2}{ }^{--}$in hemocytes, Muñoz et al. (2000) argued that this might explain the strain's ability to evade the host's oxidative microbicidal activity. The antimicrobial peptides of the Antarctic krill E. superba contain 6 fractions of different molecular weights, ranging between 245 and 709 Da. One of them, peptide CMCC-1, showed the strongest in vitro antibacterial activity against the bacteria Staphylococcus aureus (Zhao et al. 2013). CMCC-1 induces irregular morphology of $S$. aureus, destroying the cell wall and membrane (as seen with scanning and transmission electron microscopy) and inhibiting bacterial cell division (Zhao et al. 2013).

We conclude that, although oxidative stress appears to contribute to krill responses against Pseudocollinia, the main fatty acids are greatly reduced after infection with Pseudocollinia and bacterial assemblages. All krill infected with any of the 4 species of Pseudocollinia ciliates will quickly die, usually $<3 \mathrm{~d}$ after infection. The heterogeneous distribution of krill swarms decreases dispersal of infection to other krill populations, making epizootic events relatively rare or difficult to observe. It is still uncertain whether the relatively low prevalence of Pseudocollinia 
and low proportion of male infection indicate that immunological defenses may deter widespread infection within this male population. The study of the immunological defense system of krill is still in its infancy, where only E. superba, and now N. simplex, have thus far received attention in aspects of host responses to pathogens and parasites. Future studies should focus on aspects of prophenoloxidase activation, enhancement of encapsulation, nodule formation of hemocytes, formation of opsonin, antibacterial activity, antifungal activity, and healing injury to understand krill capabilities to detect and resist parasitic infections.

Acknowledgements. We thank Charles B. Miller (Oregon State University), Denis Lynn (University of British Columbia), and Michaela C. Strüder-Kypke (University of Guelph) for their valuable critiques of an earlier version of the manuscript; and many researchers, graduate students, technicians, and ship support staff at ICMyL-UNAM, CICIMARIPN, and CIBNOR for obtaining samples during the cruises and for analyzing samples. Laura Carreón-Palau (CIBNOR) provided analyses of lipids and fatty acids, and Norma O. Olguín Monroy (CIBNOR) provided analyses of oxidative stress indicators. Ira Fogel of CIBNOR provided extensive and detailed editorial help. Funding was provided by the Centro Interdisciplinario de Ciencias Marinas-IPN (SIP 2007-2014), CONACYT-FOSEMARNAT (2004-C01-144), CONACYT-SAGARPA (2005-1-11717), CONACYT Ciencia Básica (2004-45914/A-1, 2010-152850-C01 and 2012-178615C01), CIBNOR (PC0.10) and the Instituto de Ciencias del Mar y Limnología of the Universidad Nacional Autónoma de México (PAPIIT-UNAM IN20066610-3). J.G.G. is an EDIIPN and COFAA-IPN fellow. J.G.G. dedicates this work to his former PhD advisors William T. Peterson (NOAA) and Charles B. Miller (Oregon State University) for their invaluable academic support during the serendipitous discovery of histophagous ciliates in Oregon and further investigations of these then mysterious ciliates.

\section{LITERATURE CITED}

Aebi H (1984) Catalase in vitro. Methods Enzymol 105: 121-126

Ahmad S, Pardini RS (1988) Evidence for the presence of glutathione peroxidase activity towards an organic hydroperoxide in larvae of the cabbage looper moth, Trichoplusia ni. Insect Biochem 18:861-866

Alberti G, Kils U (1983) Light-and electron microscopical studies on the anatomy and function of the gills of krill (Euphausiacea, Crustacea). Polar Biol 1:233-242

Belló ARR, Fortes E, Belló-Klein A, Belló AA, Llesuy SF, Robaldo RB, Bianchini A (2000) Lipid peroxidation induced by Clinostomum detruncatum in muscle of the freshwater fish Rhamdia quelen. Dis Aquat Org 42: 233-236

Bradbury PC (1994) Parasitic protozoa of mollusks and Crustacea. In: Kreier JP (ed) Parasitic protozoa, Vol 8, 2nd edn. Academic Press, San Diego, CA, p 139-263

Bradbury PC, Goyal V (1976) The fine structure of a parasitic ciliate Terebrospira during ingestion of the exoskeleton of a shrimp Palaemonetes. Tissue Cell 8:573-582

> Bradford MM (1976) A rapid and sensitive method for the quantification of microgram quantities of protein utilizing the principle of protein-dye binding. Anal Biochem 72:248-254

Capriulo GM, Small EB (1986) Discovery of an apostome ciliate (Collinia beringensis n. sp.) endoparasitic in the Bering Sea euphausiid Thysanoessa inermis. Dis Aquat Org 1:141-146

> Capriulo GM, Pedone MJ, Small EB (1991) High apostome ciliate endoparasite infection rates found in the Bering Sea euphausiid Thysanoessa inermis. Mar Ecol Prog Ser 72:203-204

Carreón-Palau L, Parrish CC, del Angel-Rodríguez JA, Pérez-España H, Aguiñiga-García S (2013) Revealing organic carbon sources fueling a coral reef food web in the Gulf of Mexico using stable isotopes and fatty acids. Limnol Oceanogr 58:593-612

Dinno A (2015) dunn.test: Dunn's test of multiple comparisons using rank sums. R package version 1.2.4. Available at http://CRAN.R-project.org/package=dunn.test

> Folch J, Lees M, Sloane-Stanley GH (1957) A simple method for the isolation and purification of total lipids from animal tissues. J Biol Chem 226:497-509

Goldberg DM, Spooner RJ (1983) Glutathione reductase. In: Bermeyer-Ulrich H (ed) Methods of enzymatic analysis, Vol III. Enzymes, I: oxidoreductases tranferases. Verlag Chemie, Weinheim, p 258-265

Gómez-Gutiérrez J, Robinson CJ (2006) Tidal current transport of epibenthic swarms of the euphausiid Nyctiphanes simplex in a shallow, subtropical bay on Baja California peninsula, México. Mar Ecol Prog Ser 320:215-231

> Gómez-Gutiérrez J, Peterson WT, De-Robertis A, Brodeur R (2003) Mass mortality of krill caused by parasitoid ciliates. Science 301:339

Gómez-Gutiérrez J, Peterson WT, Morado JF (2006) Discovery of a ciliate parasitoid of euphausiids off Oregon, USA. Collinia oregonensis n. sp. (Apostomatida: Colliniidae). Dis Aquat Org 71:33-49

> Gómez-Gutiérrez J, Kawaguchi S, Nicol S (2009) Epibiotic suctorians and enigmatic ecto- and endoparasitoid dinoflagellates of euphausiid eggs (Euphausiacea) off Oregon, USA. J Plankton Res 31:777-786

Gómez-Gutiérrez J, Robinson CJ, Kawaguchi S, Nicol S (2010a) Parasite diversity of Nyctiphanes simplex and Nematoscelis difficilis (Crustacea: Euphausiacea) along the northwestern coast of Mexico. Dis Aquat Org 88: 249-266

Gómez-Gutiérrez J, Rodríguez-Jaramillo C, Del ÁngelRodríguez J, Robinson CJ, Zavala-Hernández C, Tremblay N, Martínez-Gómez S (2010b) Biology of the subtropical sac-spawning euphausiid Nyctiphanes simplex in the northwestern seas of Mexico: interbrood period, gonad development and lipid content. Deep-Sea Res II 57:616-630

> Gómez-Gutiérrez J, Strüder-Kypke MC, Lynn DH, Shaw TC and others (2012a) Pseudocollinia brintoni gen. nov. sp. nov. (Apostomatida: Colliniidae), a parasitoid ciliate infecting the euphausiid Nyctiphanes simplex. Dis Aquat Org 99:57-78

> Gómez-Gutiérrez J, Martínez-Gómez S, Robinson CJ (2012b) Seasonal growth, molt, and egg production of Nyctiphanes simplex (Crustacea: Euphausiacea) juveniles and adults in the Gulf of California. Mar Ecol Prog Ser 455: 173-194 
Gómez-Gutiérrez J, López-Cortés A, Aguilar-Méndez MJ, Del Angel-Rodríguez J, Tremblay N, Zenteno-Savín T, Robinson CJ (2015) Histophagous ciliate Pseudocollinia brintoni and bacterial assemblage interaction with krill Nyctiphanes simplex: I. Transmission process. Dis Aquat Org 116:213-226

Habig WH, Jakoby WB (1981) Glutathione S-tranferases (rat and human). Methods Enzymol 77:218-231

> Johnson CA, Bradbury PC (1976) Observations of the occurrence of the parasitic ciliate Synophrya in decapods in coastal waters off the southeastern United States. J Protozool 23:252-256

Kiron V (2012) Fish immune system and its nutritional modulation for preventive health care. Anim Feed Sci Technol 173:111-133

Liu YT, Chang CI, Hseu JR, Liu KF, Tsai JM (2013) Immune responses of prophenoloxidase and cytosolic manganese superoxide dismutase in the freshwater crayfish Cherax quadricarinatus against a virus and bacterium. Mol Immunol 56:72-80

Lynn DH, Gómez-Gutiérrez J, Strüder-Kypke MC, Shaw CT (2014) Ciliate species diversity and host-parasitoid codiversification in Pseudocollinia infecting krill, with description of Pseudocollinia similis sp. nov. Dis Aquat Org 112:89-102

Marsh JB, Weinstein DB (1966) Simple charring method for determination of lipids. J Lipid Res 7:574-576

$>$ Miwa S, Kamaishi T, Matsuyama T, Hayashi T, Naganobu M (2008) Histopathology of Antarctic krill, Euphausia superba, bearing black spots. J Invertebr Pathol 98: 280-286

> Mohankumar K, Ramasamy P (2006) White spot syndrome virus infection decreases the activity of antioxidant enzymes in Fenneropenaeus indicus. Virus Res 115: 69-75

> Muñoz M, Cedeño R, Rodríguez J, van der Knaap WPW, Mialhe E, Bachère E (2000) Measurement of reactive oxygen intermediate production in haemocytes of the penaeid shrimp, Penaeus vannamei. Aquaculture 191: 89-107

> Nonwachai T, Purivirojkul W, Limsuwan C, Chuchird N, Velasco M, Dhar AK (2010) Growth, nonspecific immune characteristics, and survival upon challenge with Vibrio harveyi in Pacific white shrimp (Litopenaeus vannamei) raised on diets containing algal meal. Fish Shellfish Immunol 29:298-304

Ohkawa H, Ohishi N, Yagi K (1979) Assay for lipid peroxides in animal tissues by thiobarbituric acid reaction. Anal Biochem 95:351-358

Parrilla-Taylor DP, Zenteno-Savín T, Magallón-Barajas FJ (2013) Antioxidant enzyme activity in Pacific whiteleg shrimp (Litopenaeus vannamei) in response to infection with white spot syndrome virus. Aquaculture 380-383: 41-46

Peacock EE, Olson RJ, Sosik HM (2014) Parasitic infection of the diatom Guinardia delicatula, a recurrent and eco-

Editorial responsibility: Hamish Small, Gloucester Point, Virginia, USA logically important phenomenon on the New England Shelf. Mar Ecol Prog Ser 503:1-10

Persky AM, Green PS, Stubley L, Howell CO, Zaulyanov LG, Brazeau A, Simpkins JW (2000) Protective effect of estrogens against oxidative damage to heart and skeletal muscle in vivo and in vitro. Proc Soc Exp Biol Med 223: 59-66

Philipp EER, Lipinski S, Rast J, Rosenstiel P (2011) Immune defense of marine invertebrates: the role of reactive oxygen and nitrogen species. In: Abele D, Vázquez-Medina $\mathrm{JP}$, Zenteno-Savín T (eds) Oxidative stress in aquatic ecosystems. Wiley-Blackwell, Oxford, p 236-246

R Core Team (2012) R: a language and environment for statistical computing. R Foundation for Statistical Computing, Vienna

Sato N, Murata N (1988) Membrane lipids. Methods Enzymol 167:251-259

Seear PJ, Goodall-Copestake WP, Fleming AH, Rosato E, Tarling GA (2012) Seasonal and spatial influences on gene expression in Antarctic krill Euphausia superba. Mar Ecol Prog Ser 467:61-75

Stankovic A, Rakusa-Suszczewski S (1996) Parasitic protozoa on appendages and inside the body of Euphausia superba Dana. Pol Polar Res 17:169-171

Stanley DW (2000) Eicosanoids in invertebrate signal transduction systems. Princeton University Press, Princeton, NJ

Stanley DW, Miller JS (2006) Eicosanoid actions in insect cellular immune functions. Entomol Exp Appl 119:1-13

Suzuki K (2000) Measurement of Mn-SOD and Cu, Zn-SOD. In: Taniguchi N, Gutteridge J (eds) Experimental protocols for reactive oxygen and nitrogen species. Oxford University Press, Oxford, p 91-95

Szablewski L, Hadás E (1991) Prostaglandins of Tetrahymena pyriformis GL-C and T. rostrata. Acta Protozool 30: 165-168

Tremblay N, Gómez-Gutiérrez J, Zenteno-Savín T, Robinson CJ, Sánchez-Velasco L (2010) Role of oxidative stress in seasonal and daily vertical migration of three species of krill in the Gulf of California. Limnol Oceanogr 55: 2570-2584

Vattanaviboon P, Panmanee W, Mongkolsuk S (2003) Induction of peroxide and superoxide protective enzymes and physiological cross-protection against peroxide killing by a superoxide generator in Vibrio harveyi. FEMS Microbiol Lett 221:89-95

Xu SL, Wang DL, Jia CY, Jin S, Wang CL, Zou X (2013) Effects of Vibrio alginolyticus infection on immunerelated enzyme activities and ultrastructure of Charybdis japonica gills. Aquaculture 396-399:82-88

Zhao L, Cao R, Liu Q, Wei YX, Xue Y (2011) Antimicrobial activity of polypeptides from Antarctic krill. Prog Fish Sci 4:112-116

Zhao L, Yin B, Liu Q, Cao R (2013) Purification of antimicrobial peptide from Antarctic krill (Euphausia superba) and its function mechanism. J Ocean Univ China 12:484-490

Submitted: February 5, 2015; Accepted: September 3, 2015 Proofs received from author(s): October 5, 2015 